\title{
EFFECT OF PLATE THICKNESS ON WELD SPEED IN FRICTION STIR WELDING OF AA6061-T6 AL-ALLOY PLATES
}

\author{
G. İPEKOĞLU ${ }^{1}, \ddot{\text { ö. AKCAM}}{ }^{2}$, G. CAM ${ }^{1}$ \\ ${ }^{1}$ Iskenderun Technical University. 31200 Iskenderun-Hatay, Turkey. E-mail: guven.ipekoglu@iste.edu.tr, gurel.cam@iste.edu.tr \\ ${ }^{2}$ GSI SLV-TR Kaynak Teknolojisi Test ve Mesleki Gelişim Merkezi Ltd. Şti., Çiğgem Mah., Gökkuşağı Sitesi, \\ Mavi Blok No:37-38, 06520 Balgat, Çankaya, Ankara, Turkey. E-mail: ozgur.akcam@gsi.com.tr
}

\begin{abstract}
In this study, it was aimed to determine the weld speeds required in order to obtain defect-free joints in AA6061-T6 alloy plates with two different thicknesses (namely 3,0 and $6,2 \mathrm{~mm}$ ) by friction stir welding at a constant rotational rate of 1000 rev.min- 1 . For this purpose, two different stirring tools (one tool for each plate thickness) have been obtained and used to determine suitable weld speed for each plate thickness. The microstructures of the joints obtained were investigated in both macro- and micro-scale, and their mechanical properties were determined by conducting microhardness measurements and tensile testing. The current study clearly indicated that AA6061-T6 alloy plates with different thicknesses can be successfully FS welded provided that suitable stirring tool and weld parameters are used. Moreover, it was also observed that the joint performance value of the thicker plates was somewhat lower than that of the thinner plates. This can be attributed to higher heat inputs required in order to obtain defect-free joints in thicker plates and lower cooling rates after the joining in the case of thicker plates. 42 Ref., 2 Tabl., 7 Fig.
\end{abstract}

\section{Keywords: friction stir welding, AA6061-T6, plate thickness, microstructure, mechanical properties}

Introduction. Friction stir welding (FSW) is a novel solid state joining technique used for welding low melting materials, particularly Al-alloys. In this joining method, the heat generated from the resistance of the material to plastic deformation is utilized to produce the joint. The workpieces to be joined are held against each other and a stirring tool rotating at a high rate is plunged into the workpieces and moved along the joint line. The workpieces does not melt but plasticizes by the heat generated from the resistance between the shoulder as well as the surface of the tip of the stirring tool. The plasticized workpieces are mixed together by the stirring tool as it travels along the joint line producing the joint [1-8].

This novel welding technique is at present widely employed for joining Al-alloys in industrial applications [6]. Furthermore, the method is also capable of being used in joining of Cu-alloys [9-11], Mg-alloys [12-14], Pure $\mathrm{Pb}$ [15], and even for higher temperature structural materials such as steels [1619] and Ti-alloys [4] provided that the limitations on suitable stirring tools that can withstand temperatures above $1000{ }^{\circ} \mathrm{C}$. The problems originating from the melting are not encountered in this joining technique since the workpieces do not melt during welding. These difficulties encountered in fusion joining include porosity formation and cracking in weld zone [20-26]. Moreover, it is desirable to obtain comparable mechanical properties in weld zone of a joint to those of the base plate [1]. However, the loss of strength in the weld region, both in weld nugget in the HAZ, takes place in this joining method due to dissolution and coarsening of strengthening

(C) G. İpekoğlu, Ö. Akçam, G. Çam, 2018 precipitates, respectively. Nevertheless, the loss of strength is much lower in FSW than that occurring in the fusion joining due to the lower heat inputs involved in FSW.

AA6061 Al-alloy exhibits a very good corrosion resistance. Owing to its good corrosion performance coupled with its high strength and light weight, this alloy is widely used in industrial applications. Thus, numerous studies have been conducted on friction stir weldability of these alloys [27-31]. In this study, AA6061-T6 alloy plates with two different thicknesses, namely 3,0 and 6,2 mm thick, have been friction stir welded using a different stirring tool for each. In these weld trials, the rotational rate (i.e., 1000 rev. $\mathrm{min}^{-1}$ ) chosen from the literature has been employed for both plate thickness. Thus, it was aimed to find out the influence of plate thickness on weld speed at a constant rotational rate of $1000 \mathrm{rev} . \mathrm{min}^{-1}$.

Experimental procedure. AA6061-T6 plates with two different thicknesses, namely 3,0 and $6,2 \mathrm{~mm}$, were used in this study. In order to conduct the weld trials, a welding fixture was designed and produced. This fixture is needed to hold the work pieces to be welded in a fixed position on CNC table throughout the joining process. Fig. 1 illustrates the designed welding fixture, which was used in friction stir welding of the plates. Moreover, two FSW stirring tools with different geometries and tip lengths (namely 2,8 and 6,0 $\mathrm{mm}$ ) were purchased and used in the welding of plates, Fig. 2.

The rotational rate, i.e. $1000 \mathrm{rev} \cdot \mathrm{min}^{-1}$, used in the FSW of the AA6061-T6 plates in this study is determined based on the reports existing in the literature [32-39]. This rotational rate was chosen as 


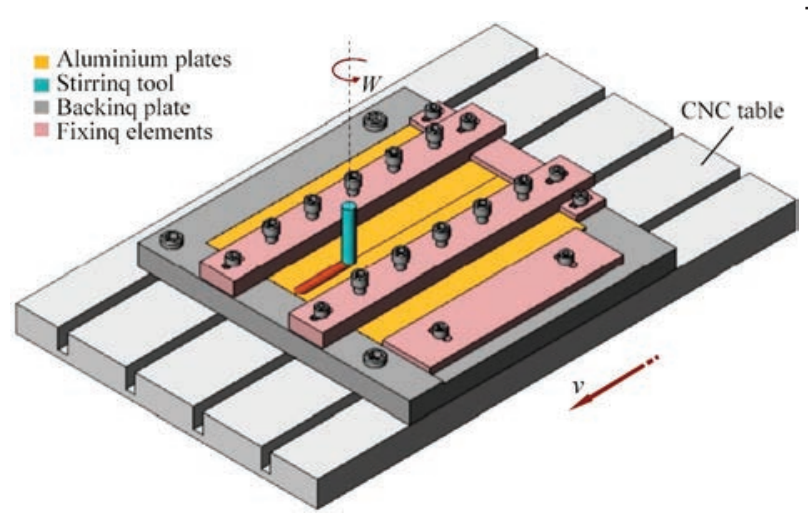

Fig. 1. The fixture designed and produced to be used in weld trials and the welding procedure

it was reported that defect-free joints produced at this rotational rate by FSW for both AA6061 and AA7075 Al-alloys plates. Furthermore, two different weld speeds were used for each plate thickness, namely $100 \mathrm{~mm} / \mathrm{min}$ and $150 \mathrm{~mm} / \mathrm{min}$ for the plate thickness of $3,0 \mathrm{~mm}$ and $50 \mathrm{~mm} / \mathrm{min}$ and $75 \mathrm{~mm} / \mathrm{min}$ for the plate thickness of $6,2 \mathrm{~mm}$. Thus, it was aimed to determine the optimum traverse speed at the constant rotational rate of 1000 rev.min-1 for each plate thickness. A tilting of stirring tool was used for both plate thickness, i.e., $0,7^{\circ}$ for $3,0 \mathrm{~mm}$ thick plates and $0,5^{\circ}$ for $6,2 \mathrm{~mm}$ thick plates. The weld parameters used were given in detail in Table 1 .

A metallography specimen and three tensile test specimens were extracted from each joint produced in order to evaluate microstructural and hardness variations within the weld region and to determine tensile properties, i.e. weld performance values. Metallography specimens were ground and polished

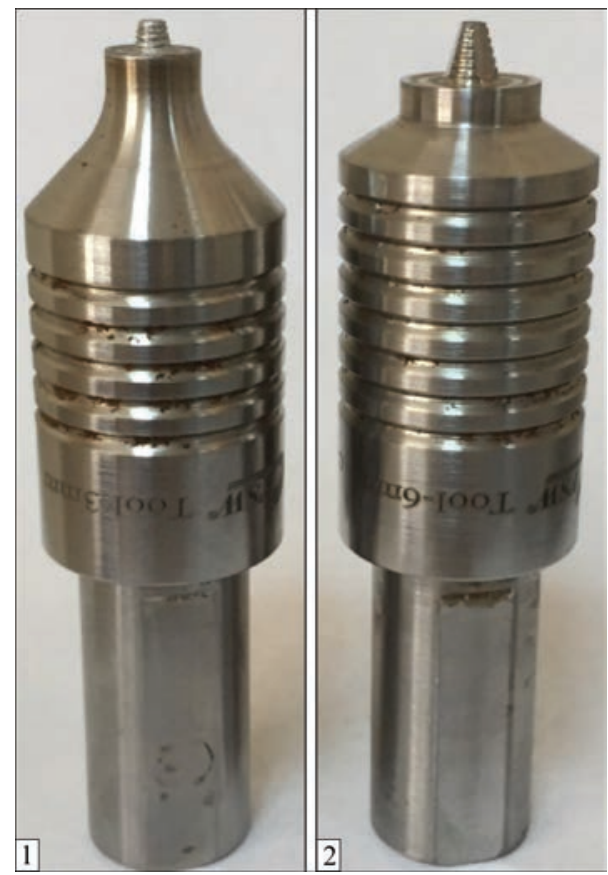

Fig. 2. The FSW stirring tools used in this study $(1-$ pin length is $2,8 \mathrm{~mm}$ and shoulder diameter is $10 \mathrm{~mm} ; 2$ - pin length is 6,0 $\mathrm{mm}$ and shoulder diameter is $15 \mathrm{~mm}$ ) [38]
Ta b le 1. The weld parameters used for FSW of AA6061-T6 alloy plates with two different thicknesses

\begin{tabular}{|c|c|c|c|c|}
\hline $\begin{array}{c}\text { Plate } \\
\text { thickness } \\
t, \mathrm{~mm}\end{array}$ & $\begin{array}{c}\text { Shoulder } \\
\text { diameter } \\
d, \mathrm{~mm}\end{array}$ & $\begin{array}{c}\text { Rotational } \\
\text { rate, } \\
\text { rev. } \mathrm{min}^{-1}\end{array}$ & $\begin{array}{c}\text { Weld speed, } \\
\mathrm{mm} / \mathrm{min}\end{array}$ & $\begin{array}{c}\text { Tool tilting, } \\
\text { Degrees }\end{array}$ \\
\hline \multirow{2}{*}{3,0} & 10 & & 100 & \multirow{2}{*}{0,7} \\
\cline { 1 - 1 } & 15,2 & 1000 & 150 & 0,70 \\
& 15 & & 75 & \multirow{2}{*}{0,5} \\
\hline
\end{tabular}

and then etched for $120 \mathrm{~s}$ using Keller's reagent for microstructural investigations and microhardness measurements. A detailed optical microscopy was conducted along the cross-sections of the joints produced in order to evaluate the microstructural alterations taking place within the weld regions. Several macro- and micrographs were taken from different regions of each joint and used to correlate the microstructure and the mechanical properties of the joints. Thus, it was aimed to determine the effect of weld speed on the microstructure and in turn on the mechanical behavior of the joints. Vickers microhardness measurements were conducted across the joint cross-sections using a load of $200 \mathrm{~g}$, loading time being $10 \mathrm{~s}$. The geometry of the tensile specimens tested was given in a previous publication [32]. All tensile tests were conducted using a loading rate of $0,1 \mathrm{~mm} / \mathrm{min}$.

Results and discussion. 1. Microstructural Aspects. Macrographs taken from the welded joints produced $(3,0 \mathrm{~mm}$ and $6,2 \mathrm{~mm}$ thick plates) are given in Fig. 3, 4, respectively. As seen from Fig. 3, both joints produced on 3,0 mm thick plates using different weld speeds, namely $100 \mathrm{~mm} / \mathrm{min}$ and $150 \mathrm{~mm} / \mathrm{min}$, did not exhibit any weld defects, such as porosity or tunnel-like void. Similarly, all the joints produced on $6,2 \mathrm{~mm}$ thick plates with different weld speeds (i.e., $50 \mathrm{~mm} / \mathrm{min}$ and $75 \mathrm{~mm} / \mathrm{min}$ ) also did not display any weld defects, Fig. 4. These results indicate that defect-free joints were successfully produced for both plates with different thickness using suitable tools and weld parameters.

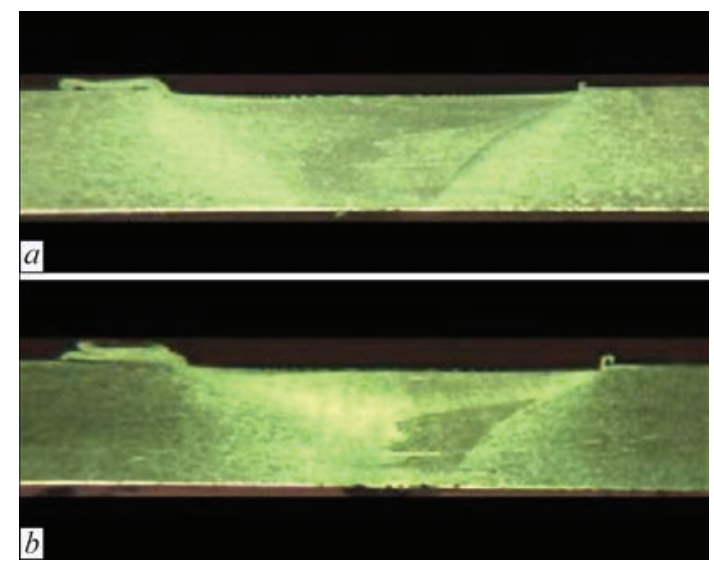

Fig. 3. Macrographs taken from the FSWed joints produced on $3,0 \mathrm{~mm}$ thick plates using a rotational rate of $1000 \mathrm{rev} . \mathrm{min}^{-1}$ : $a-100 \mathrm{~mm} / \mathrm{min} ; b-150 \mathrm{~mm} / \mathrm{min}$ 


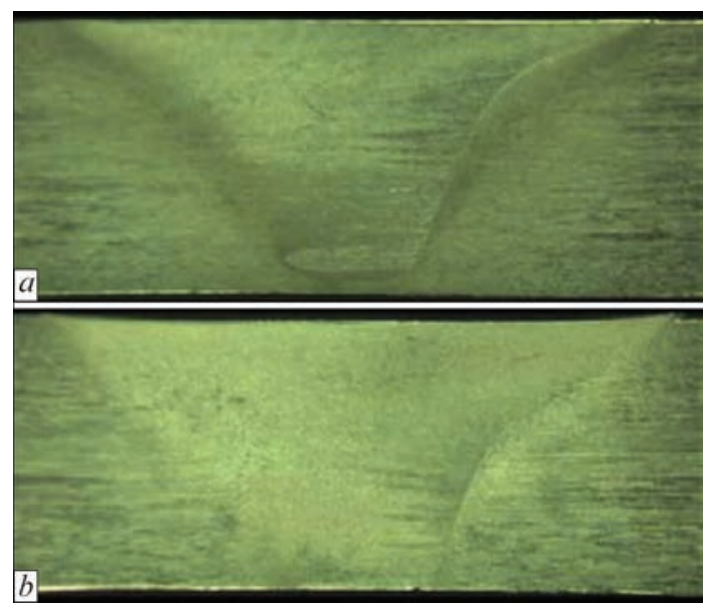

Fig. 4. Macrographs taken from the FSWed joints produced on $6,2 \mathrm{~mm}$ thick plates using a rotational rate of $1000 \mathrm{rev} \cdot \mathrm{min}^{-1}$ : $a-50 \mathrm{~mm} / \mathrm{min} ; b-75 \mathrm{~mm} / \mathrm{min}$

Moreover, it was also clearly observed that the weld regions of the joints obtained on thicker plates were wider than those exhibited by the joints produced on thinner plates. These results were not surprising since the shoulder and pin diameters of the stirring tool used in FSW of thicker plates are larger. These results also indicate that the rotational rate of 1000 rev. $\mathrm{min}^{-1}$ can be used for both plate thicknesses.

The microstructures of both AA6061-T6 base plates with two different thicknesses (i.e., 3,0 and $6,2 \mathrm{~mm}$ ) used in this study are shown in Fig. 5, $a$ and $6, a$, respectively. As seen from these micrographs, both base plates exhibit a microstructure consisting of alpha grains containing randomly distributed large particles which are readily visible in optical microscopy. As reported in earlier publications [33, 34], the particles randomly oriented in alpha matrix are script-like $\mathrm{Fe}_{3} \mathrm{SiAl}_{12}$ particles and round $\mathrm{Mg}_{2} \mathrm{Si}$ particles. Alpha grains existing in the microstructures of both base plates are coarse-grained and no clear difference was observed in the alpha grain size between the microstructures of the plates with different plate thicknesses. The microstructure of AA6061 alloy also contains very fine grained $\mathrm{Mg}_{2} \mathrm{Si}$ precipitates homogeneously distributed within the alpha grains, which result in strengthening in T6 temper condition of this alloy. However, these strengthening precipitates are extremely fine, so that they are not visible under optical microscope, and even in scanning electron microscopy.

As clearly seen from Fig. 5, grain refinement took place within the dynamically recrystallized zones (DXZs) of the joints produced on $3,0 \mathrm{~mm}$ thick AA6061-T6 plates using two different weld speeds, namely 100 and $150 \mathrm{~mm} / \mathrm{min}$. Moreover, it was also observed that the joint obtained using slower weld speed (i.e., $100 \mathrm{~mm} / \mathrm{min}$ ) exhibited coarser grains in the microstructure of the DXZ (Fig. 5,b) than

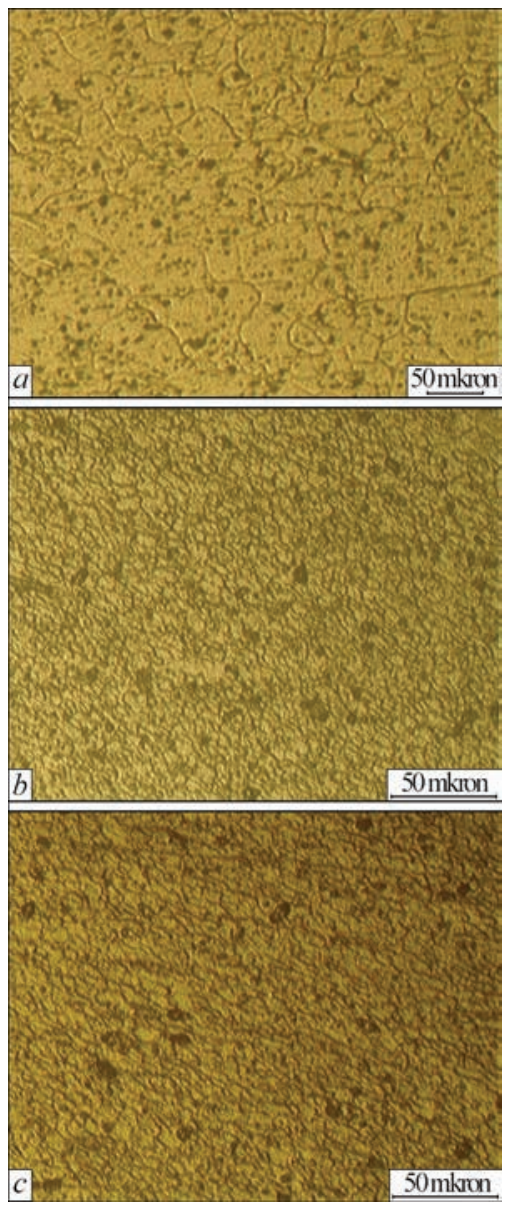

Fig. 5. Optical micrographs of 3,0 $\mathrm{mm}$ thick base plate and DXZs of the joints produced on this plate: $a-$ base plate; $b-\mathrm{DXZ}$ of the joint produced using a weld speed of $100 \mathrm{~mm} / \mathrm{min} ; c-\mathrm{DXZ}$ of the joint produced using a weld speed of $150 \mathrm{~mm} / \mathrm{min}$

those of the joint produced at higher weld speed (i.e., $150 \mathrm{~mm} / \mathrm{min}$ ), Fig. 5, $c$. This indicates that the extent of grain refinement was lower in the joint obtained at slower weld speed, which is attributed to the higher heat input involved in this case leading to grain coarsening.

Similar results were also observed in the joints obtained on thicker plates, i.e. $6,2 \mathrm{~mm}$, using two different weld speeds (namely 50 and $75 \mathrm{~mm} / \mathrm{min}$ ), Fig. 6. Grain refinement also occurred within the DXZs of these joints as well and finer alpha grains were observed in the microstructures of the DXZs than those in the microstructure of the base plate. When the grain sizes of the microstructures of these joints are compared it can be seen that the joint produced at higher welding speed displayed finer grains than those of the joint obtained at lower weld speed, Figs. 6, $b, c$. This result is again attributed to the lower heat input involved in the case of higher weld speed resulting in finer grains within the DXZ.

Furthermore, the extent of the grain refinement taking place in the DXZs of the joints produced on thinner plates (i.e., $3,0 \mathrm{~mm}$ ) is higher than that occurring in the DXZ of the joints obtained on thicker plates (i.e., 6,2 $\mathrm{mm}$ ). In other words, the grains in 
the DXZs of the thinner joints are finer than those in DXZs of thicker joints, Fig. 5, 6. This is believed to be due to the fact that heat input involved in FSW of thinner plates are in general much lower than those involved in FSW of thicker plates resulting from the use of larger stirring tools for thicker plates, as well as lower cooling rates involved in thicker plates after the welding.

2. Mechanical Properties. Vickers microhardness measurements $\left(H V_{0,2}\right)$ were taken across the weld cross-section from numerous locations on a line in the mid-thickness of the welded joint using a load of $200 \mathrm{~g}$ in order to determine the hardness profiles of all the joints produced in this study. Fig. 7 illustrates
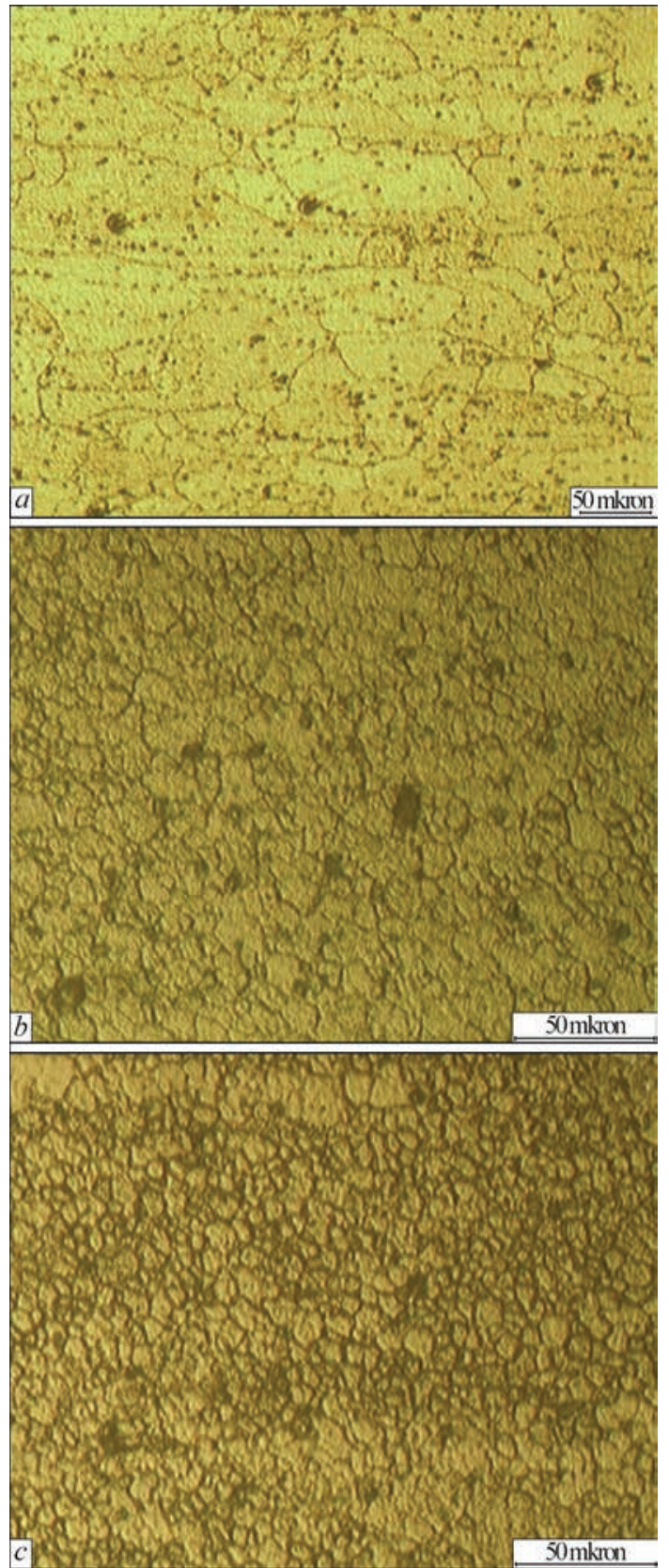

Fig. 6. Optical micrographs of 6,2 $\mathrm{mm}$ thick base plate and DXZs of the joints produced on this plate: $a$ - base plate; $b-\mathrm{DXZ}$ of the joint produced using a weld speed of $50 \mathrm{~mm} / \mathrm{min} ; c-\mathrm{DXZ}$ of the joint produced using a weld speed of $75 \mathrm{~mm} / \mathrm{min}$ the obtained hardness profiles from both joints with different plate thicknesses, namely 3,0 and $6,2 \mathrm{~mm}$, produced using different weld speeds. These hardness profiles clearly indicate that a hardness loss took place in all the joints. On the other hand, metallographic investigations displayed that grain refinement occurred within the weld nugget of all the joints, Fig. 5, 6. It was expected that this grain refinement would increase the hardness in the weld region. However, the base plate used in this study is in the artificially aged temper condition (i.e., T6) and the strength in this temper condition originates mainly from very fine homogeneously distributed strengthening precipitates within the alpha grains. When this alloy is exposed to heat after aging, such as welding, dissolution or coarsening of the strengthening precipitates takes place depending on the level of temperature involved, thus resulting in a loss in hardness. This hardness loss occurs both in heat affected zone (HAZ) and in the weld nugget. The reason of the hardness loss in the weld nugget is the dissolution of the strengthening precipitates whereas the hardness loss in the HAZ is due to the coarsening of the precipitates as a result of overaging [40].

The hardness minimum lies within the overaged HAZ regions on both sides of the weld nugget since hardness loss in the weld nugget is partly recovered by the grain refinement taking place there, giving rise to a W-shaped hardness profile (Fig. 7). This type of hardness profile is very typical of this alloy as the case in fusion welding [5, 6, 20, 22, 23]. Moreover, a less significant hardness loss in the weld region was displayed by the joints produced at higher weld
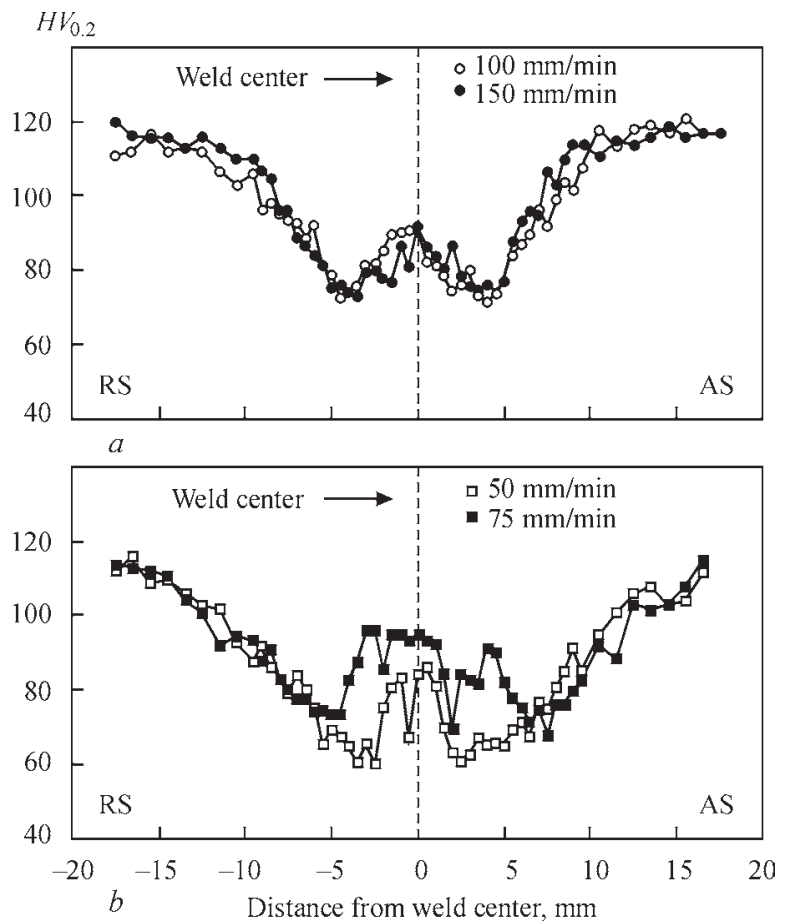

Fig. 7. Hardness profiles of the joints produced: $a-3,0 \mathrm{~mm}$ thick joint; $b-6,2 \mathrm{~mm}$ thick joint 
Ta b l e 2. Tensile test results

\begin{tabular}{|c|c|c|c|c|c|c|c|}
\hline Specimen & $\begin{array}{l}\text { Weld speed, } \\
\mathrm{mm} / \mathrm{min}\end{array}$ & $\begin{array}{l}\% 0,2 \text { Proof } \\
\text { stress, MPa }\end{array}$ & $\begin{array}{l}\text { Tensile strength, } \\
\mathrm{MPa}\end{array}$ & Elongation, \% & $\begin{array}{c}\text { Proof stress } \\
\text { performance, } \\
\%\end{array}$ & $\begin{array}{c}\text { Tensile strength } \\
\text { performance, } \\
\%\end{array}$ & $\begin{array}{c}\text { Elongation } \\
\text { performance, } \\
\%\end{array}$ \\
\hline $\mathrm{BM}$ & -- & $276^{*}$ & $310^{*}$ & $12 *$ & --- & --- & --- \\
\hline \multirow{2}{*}{$\begin{array}{l}\text { FSWed joint } \\
(3,0 \mathrm{~mm})\end{array}$} & 100 & $\begin{array}{l}170 ; 161 ; \\
162(164)\end{array}$ & $\begin{array}{l}220 ; 220 ; \\
221(220)\end{array}$ & $\begin{array}{l}4,2 ; 4,3 ; \\
4,1(4,2)\end{array}$ & 59 & 71 & 35 \\
\hline & 150 & $\begin{array}{l}178 ; 183 \\
181(181)\end{array}$ & $\begin{array}{l}224 ; 233 ; \\
230(229)\end{array}$ & $\begin{array}{l}4,5 ; 4,2 \\
4,4(4,4)\end{array}$ & 66 & 74 & 37 \\
\hline \multirow{2}{*}{$\begin{array}{l}\text { FSWed joint } \\
(6,2 \mathrm{~mm})\end{array}$} & 50 & $\begin{array}{l}140 ; 146 \\
147(144)\end{array}$ & $\begin{array}{l}200 ; 211 ; \\
210(207)\end{array}$ & $\begin{array}{l}3,9 ; 4,1 ; \\
4,1(4,0)\end{array}$ & 52 & 67 & 33 \\
\hline & 75 & $\begin{array}{l}148 ; 148 ; \\
150(149)\end{array}$ & $\begin{array}{l}211 ; 210 ; \\
212(211)\end{array}$ & $\begin{array}{l}4,9 ; 5,3 ; \\
4,6(4,9)\end{array}$ & 54 & 68 & 41 \\
\hline
\end{tabular}

Note: Average values are given in bold and parenthesis. *These mechanical properties of the base plate are taken from the literature.

speeds than those obtained at lower speeds for both plate thickness as seen from Fig. 7. This is attributed to lower heat inputs involved in the welds conducted at higher weld speeds.

It was also observed that the joints produced on $6,2 \mathrm{~mm}$ thick plates exhibited a more significant hardness loss within the weld region than the joints obtained on thinner plates, particularly the joint procuded using a weld speed of $50 \mathrm{~mm} / \mathrm{min}$, Fig. 7 , $b$. The lowest hardness observed within the weld region of the $6,2 \mathrm{~mm}$ thick joint produced at a welding speed of $50 \mathrm{~mm} / \mathrm{min}$ was about $60 \mathrm{HV}$, while the minimum hardness in the $3,0 \mathrm{~mm}$ thick joints was $72 H V$. This result is in good agreement with the metallographic invsetigations which indicated a more significant grain refinement within the weld nugget of the $3,0 \mathrm{~mm}$ thick joints than the joints produced on thicker plates, Fig. 5, 6. As discussed in the microstructural aspects section earlier, the reason for this is the higher shoulder and tip dimeter of the stirring tool used for joining thicker plates, thus leading to higher heat input during welding, as well as lower cooling rates involved in the thicker plates after joining. Moreover, the witdh of the weld region where a hardness loss occurred is larger in the case of the thick plate joints (approximately $15 \mathrm{~mm}$ wide, Fig. $7, b$ ) than thin plate joints (being about $10 \mathrm{~mm}$ wide, Fig. 7, a). This result is also in good agreement with the macrographs taken from the joints, Fig. 3, 4.

The tensile test results of the joints are summarized in Table 2. Three tensile test were conducted for each joint and the average of these three test results were calculated, and the average values calculated are given in Table in bold and parenthesis. These average values were used in the calculations of the joint performance values. Three joint performance values, namely proof stress performance, tensile strength performance and ductility performance, were determined for all the joints produced. The minimum tensile properties were taken from the tensile data existing in the literature for AA6061-T6 plates and used in the calculation of performance values. Three performance values were determined as explained below:

Proof stress performance $(\%)=(\% 0,2$ Proof stress of welded joint $/ \% 0,2$ Proof stress of base plate) $\times 100$

Tensile strength performance $(\%)=($ Tensile strength of welded joint / tensile strength of base plate) $\times 100$

Elongation performance $(\%)=(\%$ Elongation of welded joint $/ \%$ Elongation of base plate $) \times 100$

As seen from Table 2, high weld performance values (i.e., proof stress and tensile strength performance values) have been obtained from all the joints produced on both plate thicknesses at a rotational rate of $1000 \mathrm{rev}$. $\mathrm{min}^{-1}$ using tools with different geometries (Fig. 2) and two different weld speeds. However, the joint produced with higher weld speed at each plate thickness exhibited higher weld strength performance values. The maximum proof stress and tensile strength performance values obtained from the specimens extracted from the $3,0 \mathrm{~mm}$ thick joints were displayed by the joint produced at a welding speed of $150 \mathrm{~mm} / \mathrm{min}$, which are $66 \%$ and $74 \%$, respectively.

On the other hand, the maximum strength performance values were exhibited by the $6,2 \mathrm{~mm}$ thick joints produced at a welding speed of $75 \mathrm{~mm} / \mathrm{min}$, which are $54 \%$ and $68 \%$, respectively. These values are lower than those obtained from the 3,0 $\mathrm{mm}$ thick joints. These results are in good agreement with the hardness profiles of the joints, Fig. 7. As seen from Fig. 7, the hardness loss in the weld regions of the $6,2 \mathrm{~mm}$ thick joints were more significant than those observed in the 3,0 mm thick joints. Moreover, the ductility performance values exhibited by all the joints are relatively low, ranging from $33 \%$ to $41 \%$. This can be attributed to the strength undermatching in the weld region. Since the strength is much lower within the weld region than that of the base plate the elongation takes place only within the weld region section of the transverse tensile test specimens and the base plate sections do not yield (it is in the elastic region throughout the test) and thus do not contribute to the total elongation. In the case of strength undermatching joints, the stress concentration and, thus, fracture take place in the lower strength 
weld metal region (confined plasticity), leading to an increase of constraint within the weld region and, thus, significantly lower ductility levels. This confined plasticity is also quite common in fusion welded or diffusion bonded joints with a strength undermatching weld region [20-26, 41, 42].

Conclusions. In this study, AA6061-T6 Alalloy plates with two different thicknesses, i.e., 3,0 and $6,2 \mathrm{~mm}$, have been successfully friction stir welded at a rotation rate of $1000 \mathrm{rev} . \mathrm{min}^{-1}$. The following conclusions have been withdrawn from this experimental work:

- it was observed that the tool geometry plays an important role on the heat input the workpieces experience during FSW. The shoulder and tip diameters of the tool used for FSW thicker plates are larger. Thus, the total surface area of the tool is larger which in turn results in higher frictional heat. As a result of this, a higher heat input is applied to the workpieces to be welded, leading to wider weld width in the thicker joints;

- a grain refinement was observed in the weld nuggets of all the joints produced due to dynamic recrystallization. The grains in the weld nugget are finer in general in thinner joints than those of the thicker joints due to the lower heat input involved in FSW of thinner plates. For each plate thickness, the joint produced using higher weld speed exhibited finer grains due the lower heat input involved at higher weld speeds;

- a more significant hardness decrease took place within the weld regions of the thicker joints. This can also be attributed to the higher heat inputs involved;

- due to the lower heat involved, the specimens extracted from the thinner joints displayed in general higher proof stress and tensile strength performances;

- on the other hand, ductility performances of all the joints are low, the maximum value being $41 \%$. This is not surprising since lower ductility levels are obtained from the transverse tensile specimens extracted from the joints with strength undermatching weld zone due to confined plasticity.

\section{References}

1. Thomas, W.M., Nicholas, E.D., Needham, J.C., Murch, M.G., Temple-Smith, P., and Dawes, C.J., December 1991. International Patent Application No. PCT/GB92/02203

2. Mishra, R.S., and Ma, Z.Y. Materials Science and Engineering: R: Reports, 2005, 50, pp. 1-78.

3. Nandan, R., DebRoy, T., and Bhadeshia, H.K.D.H. Progress in Materials Science, 2008, 53 (6):pp. 980-1023.

4. Çam, G. International Materials Reviews, 2011, 56, pp. 1-48.

5. Cam, G., and Mistıkoğlu, S. Journal of Materials Engineering and Performance, 2014, 23 (6), pp. 1936-1953.

6. Cam, G., and İpekoğlu, G. The International Journal of Advanced Manufacturing Technology, 2017, 91 (5-8), pp. 1851-1866.

7. Çam, G., İpekoğlu, G., Küçükömeroğlu, T., and Aktarer, S.M. Journal of Achievements in Materials and Manufacturing Engineering (JAMME), 2017, 80 (2), pp. 65-85.
8. Kashaev, N., Ventzke, V., and Çam, G. to be published in J. Manuf. Proc., 2018

9. Çam, G., Mistikoglu, S., and Pakdil, M. Welding Journal, 2009, 88 (11), pp. 225s-232s

10. Cam, G., Serindağ, H.T., Cakan, A., Mistıkoğlu, S., and Yavuz, H. Materialwissenschaft und Werkstofftechnik, 2008, 39 (6), pp. 394-399.

11. Küçükömeroğlu, T., Şentürk, E., Kara, L., İpekoğlu, G., and Çam, G. Journal of Materials Engineering and Performance (JMEPEG), 2016, 25 (1), pp. 320-326.

12. Yang, J., Xiao, B.L., Wang, D., and Ma, Z.Y. Materials Science and Engineering A, 2010, A527 (3), pp. 708-714.

13. Zhang, D., Suzuki, M., and Maruyama, K. Scripta Materialia, 2005, 52 (9), pp. 899-903.

14. Lim, S.G., Kim, S.S., Lee, C.G., Yim C.D., and Kim, S.J. Metallurgical and Materials Transactions A, 2005, 36A (6), pp. 1609-1612.

15. Günen, A., Kanca, E., Demir, M., Çavdar, F., Mistikoğlu, S., and Çam, G. Indian Journal of Engineering \& Materials Sciences, 2018, 25 (1), pp. 26-32.

16. Thomas, W.M., Threadgill, P.L., and Nicholas, E.D. Science and Technology of Welding and Joining, 1999, 4 (6), pp. 365372.

17. Ueji, R., Fujii, H., Cui, L., Nishioka, A., Kunishige, K., and Nogi, K. Materials Science and Engineering A, 2006, A423, pp. 324-330.

18. Miyazawa, T., İwamoto, Y., Maruko, T., and Fujii, H. Science and Technology of Welding and Joining, 2012, 17 (3), pp. 213-218.

19. Küçükömeroğlu, T., Aktarer, S.M., İpekoğlu, G., and Cam, G. to be published in International Journal of Minerals, Metallurgy and Materials, 2018

20. Pakdil, M., Çam, G., Koçak, M., and Erim, S. Mater. Sci. Eng. A, 2011, 528 (24), pp. 7350-7356.

21. Çam, G. and Koçak, M. J. Mater. Sci., 2007, 42 (17), pp. 7154-7161.

22. Çam, G., Ventzke, V., dos Santos, J.F., Koçak, M., Jennequin, G., and Gonthier-Maurin, P. Sci. Technol. Weld. Join., 1999, 4 (5), pp. 317-323.

23. Çam, G., Ventzke, V., dos Santos, J.F., Koçak, M., Jennequin, G., Gonthier-Maurin, P., Penasa, M., and Rivezla, C. Prakt. Metallogr., 1999, 36 (2), pp. 59-89.

24. Cam, G., Güçlüer, S., Cakan, A., and Serindağ, H.T. Mat.wiss. u. Werkstofftech., 2009, 40 (8), pp. 638-642.

25. Dos Santos, J., Cam, G., Torster, F., Insfran, A., Riekehr, S., Ventzke, V., and Koçak, M. Welding in the World, 2000, 44 (6), pp. 42-64.

26. Von Strombeck, A., Çam, G., Dos Santos, J.F., Ventzke, V., and Koçak, M. 'A comparison between microstructure, properties, and toughness behavior of power beam and friction stir welds in Al-alloys', Proc. of the TMS 2001 Annual Meeting Aluminum, Automotive and Joining (New Orleans, Louisiana, USA, February 12-14, 2001), eds: S.K. Das, J.G. Kaufman, and T.J. Lienert, pub.: TMS, Warrendale, PA, USA, 2001, pp. 249-264.

27. Trueba, L., Heredia, G., Rybicki, D., and Johannes L.B. Journal of Materials Processing Technology, 2015, 219, pp. 271-277.

28. Cao, J.Y., Wang, M., Kong, L., Zhao, H.X., and Chai, P. Materials Characterization, 2017, 128, pp. 54-62.

29. Liu, H.J. ,Hou, J.C., Guo H. Materials \& Design, 2013, 50, pp. 872-878.

30. Elangovan, K., and Balasubramanian, V. Materials Characterization, 2008, 59 (9), pp. 1168-1177.

31. Feng, A. H., Chen, D. L., and Ma, Z. Y. Metallurgical and Materials Transactions A, 2010, 41A, pp. 2626-2641.

32. İpekoğlu, G., Kıral, B. G., Erim, S., and Çam, G. Materiali in Tehnologije, 2012, 46 (6), pp. 627-632.

33. İpekoğlu, G., Erim, S., Kıral, B. G., and Çam, G. Kovove Materialy, 2013, 51 (3), pp. 155-163.

34. İpekoğlu, G., Erim, S., and Çam, G. Metallurgical and Materials Transactions A, 2014, 45A (2), pp. 864-877. 
35. İpekoğlu, G., Erim, S., and Çam, G. The International Journal of Advanced Manufacturing Technology, 2014, 70 (1), pp. 201-213.

36. İpekoğlu, G., and Çam, G. Metallurgical and Materials Transactions A, 2014, 45A (7), pp. 3074-3087.

37. Çam, G., İpekoğlu, G., and Serindağ, H.T. Science and Technology of Welding and Joining, 2014, 19 (8), pp. 715720.

38. İpekoğlu, G., Akçam, Ö., and Çam, G. 'Effect of plate thickness on weld speed in friction stir welding of AA6061-T6 Al-alloys plates', Proc. of the 10th Welding Technology
National Congress and Exhibition, 17-18 November 2017, Ankara, Turkey, pp. 63-75 (in Turkish).

39. Woo, W., Choo,H., Brown, D.W., and Feng, Z. Metallurgical and Materials Transactions A, 2007, 38A, pp. 69-76.

40. İpekoglu G., Akçam Ö., and Çam G. Afyon Kocatepe University Journal of Science and Engineering (AKU J. Sci. Eng.), 2018, 18 (1), 015901, pp. 324-335 (in Turkish)

41. Koçak, M., Pakdil, M., and Çam, G. Sci. Technol. Weld. Join., 2002, 7 (4), pp. 187-196.

42. Çam, G., Koçak, M., Dobi, D., Heikinheimo, L., and Siren, M. Science and Technology of Welding and Joining, 1997, 2 (3), pp. 95-101

\title{
ВПЛИВ ТОВЩИНИ ПЛАСТИН 3 АЛЮМІНІЄВОГО СПЛАВУ АА6061-Т6 НА ШВИДКІСТЬ ЗВАРЮВАННЯ ТЕРТЯМ 3 ПЕРЕМІШУВАННЯМ Ж. ІПЕКОГЛИ ${ }^{1}$, О. АККАМ ${ }^{2}$ Ж. КАМ ${ }^{1}$
}

\author{
${ }^{1}$ Технічний університет Іскендерун. 31200 Іскендерун-Хатай, Туреччина. \\ E-mail: guven.ipekoglu@iste.edu.tr, gurel.cam@iste.edu.tr \\ ${ }^{2}$ GSI SLV-TR Kaynak Teknolojisi Test ve Mesleki Gelişim Merkezi Ltd. Şti., Çiğdem Mah., Gökkuşağı Sitesi, \\ Маві Блок №: 37-38, 06520 Балгат, Чанкая, Анкара, Туреччина. E-mail: ozgur.akcam@gsi.com.tr
}

\begin{abstract}
Робота спрямована на визначення швидкості зварювання, необхідної для отримання бездефектних з'єднань пластин 3 алюмінієвого сплаву АА6061-Т6 товщиною 3,0 та 6,2 мм при зварюванні тертям з перемішуванням (швидкість обертання інструменту 1000 об / хв.). Для цього було використано два різних інструменти (для кожної товщини пластини). Мікроструктура металу з'єднань була досліджена як в макро-, так і в мікромасштабном вигляді, а їх механічні властивості були визначені шляхом проведення вимірювань мікротвердості та випробувань на розтягування. У дослідженні чітко встановлено, що пластини зі сплаву АА6061-Т6 з різною товщиною можуть бути успішно з'єднані за умови, що використовуються відповідні інструменти і параметри зварювання. Крім того, було також відзначено, що продуктивність зварювання більш товстих пластин була дещо нижчою, ніж у більш тонких пластин. Це можна пояснити більш високими витратами тепла, необхідними для отримання бездефектних з'єднань більш товстих пластин і більш низькими швидкостями охолодження після з’єднання в разі більш товстих пластин. Бібліогр. 42, табл. 2, рис. 7.
\end{abstract}

Ключов $і$ слов а: зварювання тертям з перемішуванням, АА6061-Т6, товщина пластини, мікроструктура, механічні властивості

\author{
ВЛИЯНИЕ ТОЛЩИНЫ ПЛАСТИН \\ ИЗ АЛЮМИНИЕВОГО СПЛАВА АА6061-Т6 НА СКОРОСТЬ СВАРКИ \\ ТРЕНИЕМ С ПЕРЕМЕШИВАНИЕМ \\ Ж. ИПЕКОГЛЫ ${ }^{1}$, О. АККАМ ${ }^{2}$ Ж. КАМ ${ }^{1}$ \\ ${ }^{1}$ Технический университет Искендерун. 31200 Искендерун-Хатай, Турция. \\ E-mail: guven.ipekoglu@iste.edu.tr, gurel.cam@iste.edu.tr \\ ${ }^{2}$ GSI SLV-TR Kaynak Teknolojisi Test ve Mesleki Gelişim Merkezi Ltd. Şti., Çiğdem Mah., Gökkuşağı Sitesi, \\ Мави Блок №: 37-38, 06520 Балгат, Чанкая, Анкара, Турция. E-mail: ozgur.akcam@gsi.com.tr
}

Работа направлена на определение скорости сварки, необходимой для получения бездефектных соединений пластин из алюминиевого сплава АА6061-Т6 толщиной 3,0 и 6,2 мм при сварке трением с перемешиванием (скорость вращения инструмента 1000 об/мин). При этом были использованы два разных инструмента (для каждой толщины пластины). Микроструктура металла соединений была исследована как в макро-, так и в микромасштабном виде, а их механические свойства были определены путем проведения измерений микротвердости и испытаний на растяжение. В исследовании четко установлено, что пластины из сплава АА6061-Т6 с различной толщиной могут быть успешно соединены при условии, что используются подходящие инструменты и параметры сварки. Кроме того, было также отмечено, что производительность сварки более толстых пластин была несколько ниже, чем у более тонких пластин. Это можно объяснить более высокими затратами тепла, необходимыми для получения бездефектных соединений более толстых пластин и более низкими скоростями охлаждения после соединения в случае более толстых пластин. Библиогр. 42, табл. 2 , рис. 7.

Ключев в е слова: сварка трением с перемешиванием, АA6061-T6, толщина пластины, микроструктура, механические свойства 